\title{
Effect of economic and security challenges on the Nigerian health sector.
}

\author{
Folashade T Alloh ${ }^{1}$, Pramod R Regmi ${ }^{1,2}$
}

1. Faculty of Health and Social Sciences, Bournemouth University, UK

2. Visiting Research Fellow, Chitwan Medical College, Tribhuvan University,

Nepal; Datta Meghe Institute of Medical Sciences, India

\section{DOI: https://dx.doi.org/10.4314/ahs.v17i2.37}

Cite as: Alloh FT, Regmi PR. Effect of economic and security challenges on the Nigerian health sector. Afri Health Sci. 2017;17(2): 591-592. bttps:/ / dx.doi.org/10.4314/abs.v17i2.37

Dear Editor,

The call on the federal Government of Nigeria to declare a state of emergency in the Nigerian health sector by its federal law makers has come at a time when the health sector of the country is unfortunately in a dysfunctional state. This has been furthered by the fact that the Nigerian economy has suffered setbacks in recent times, particularly with the official announcement of having entered an economic recession by Finance Minister for the federal government in July 2016, after annual inflation increased to $17.1 \%$, the highest in the last decade ${ }^{1}$. This came following the steep fall in the price of crude oil from $\$ 115$ in 2014 to the current $\$ 35$ per barrel ${ }^{2}$. Crude oil accounts for $75 \%$ of Nigeria's economy, so the fall in oil prices, therefore, has a significant impact on all sectors of the country. In addition to the drop in oil prices, Nigeria is fighting insurgency by Boko Haram, one of the most deadly terror groups in the world. There are also Niger-Delta militants that are bombing oil pipelines in the South-South region of Nigeria in an agitation against the government disrupting the production of crude oil in the area.

In the plethora of issues facing Nigeria as a nation, the health of the citizens became a low priority for the government, especially those in crisis-ridden area. For example, the United Nation Children's Fund (UNICEF) in July 2016 announced the withdrawal of its humanitarian
Corresponding author:
Folashade T Alloh,
Faculty of Health and
Social Sciences,
Bournemouth University, UK
Email: falloh@bournemouth.ac.uk

workers to Borno State insurgency victims, due to the threat to the life of health workers in the area. Following the humanitarian workers withdrawal, UNICEF has warned that more than 2 million crisis victims are in dire need of humanitarian aid with more than 1.2 million internally displaced people ${ }^{3}$. This has resulted in more than an estimated 244,000 children having severe malnutrition, with 49,000 at risk of dying if humanitarian aid is not provided in areas mostly affected by the insurgency. The level of acute malnutrition recorded between July and August 2016 was well above the 15\% threshold and classified as critical with some cases higher than $50 \%$ representing about half of children affected.

Already in some Northern states more than $72 \%$ of health centres in Yobe and 60\% in Borno have been destroyed due to the insurgency. These challenges have resulted in poor health outcomes for these states' citizens. For example, the African health observatory report by World Health Organisation (WHO), stated that Nigeria experienced the fourth highest maternal deaths among African countries. This led to over $820 / 100,000$ deaths per live births and 109/100 000 children under five deaths per live births translating to 58, 000 women and 750, 000 children dying in $2015^{4}$.

Nigerian life expectancy which is put at 53 for males and 56 years for females is among the lowest in the world. Similarly, in 2015 , less than half $(49 \%)$ of children in the country were able to receive immunisation of DPT/Penta dose which was far below the $90 \%$ target in the Millennium development goal 4 to reduce child mortality. More than half of children in need of immunisation were not reached in 2015 for vaccination against measles and rubella which raises health concerns. $\mathrm{WHO}^{5}$ has reported three cases of polio in crisis-ridden areas of Borno state: this was after the country reported two years of no polio 
cases. However, the re-emergence of the two cases might be as a result of the inaccessibility of health workers to reach children in crisis areas.

After the Abuja benchmark declaration in 2001 to spend at least $15 \%$ of countries' yearly budget on the health sector, Nigeria has yet to meet the target in any given year. The impact of poor health sector funding is amplified during this worst recession in over a decade in Nigeria. In addition, the federal ministry of health reported reduction in budgetary allocation to the health sector as a gradual decrease from N264.46bn (approx. \$839 millions) equivalent to $6.0 \%$ of the national budget in 2014 to N257.38bn (approx. $\$ 816$ millions) equivalent to $4.23 \%$ annual budget in $2016^{6}$. This has resulted as an effect of economic recession, causing the GDP to drop by $-2.06 \%$ in 2016 as reported by National bureau of statistics ${ }^{1}$. With the lack of funding in Nigeria, the health sector remains incapable of dealing with the health challenges facing the country. These range from poor healthcare framework and co-ordination, fragmented services, scarcity of medicines and medical supplies, old and decaying infrastructure, lack of healthcare access to all, to poor quality of healthcare service delivery and increasing health inequality gaps between rich and poor citizens. In addition, allegations of corruption surrounding many of the country's lawmakers in different scandals over the years have had an effect on the health sector. The need to push health into the forefront of national issues cannot be over emphasised.

The need for the Nigerian federal government to implement the Abuja 2001 declaration benchmark commitment, by setting aside $15 \%$ of its yearly budget to revive primary health care in each ward of the federation-as this is the first contact for most poor citizens of the country-is particularly apparent. There is an urgent need for framework and policy regarding sustainable immunisation financing, and also the need for a universal health insurance scheme. In order for the need-based resource mobilisation, development partners' contribution should be clearly identified and represented in the budget to enable transparency and accountability.

The fight against insurgency and economic challenges should not take way attention due to the health sector, as an effective functioning healthcare system is essential for national health security. A way forward will be to look for alternative funding sources outside budgetary allocations and international grants.

\section{Reference}

1. National Bureau of statistics. Nigerian gross Domestic product report Q2 2016. 2016. http://www.nigerianstat. gov.ng/report/434

2. World economic forum. What's behind the drop in oil prices?. 2016. https://www.weforum.org/agenda/2016/03/what-s-behind-the-drop-in-oil-prices/

3. Burki T. Health crisis intensifying in Nigeria's Borno state. The Lancet 2016; 388 (10045) supp: 633-730.

4. WHO. African Atlas of African Health Statistics 2016 - Health situation analysis of the African Region. 2016. http://www.aho.afro.who.int/en/atlas/atlas-african-health-statistics-2016-health-situationanalysis-of-the-african-region

5. WHO. Government of Nigeria reports 2 wild polio cases, first since July 2014. 2016. http://www.who.int/ mediacentre/news/releases/2016/nigeria-polio/en/

6. WHO 2007. High-level debate tackled need for improved international health. http://www.who.int/worldhealth-day/previous/2007/activities/global_event/en/ 